\title{
Optimizing land use for the delivery of catchment ecosystem services
}

\author{
Donnacha G Doody ${ }^{1 * \dagger}$, Paul JA Withers ${ }^{2 \dagger}$, Rachael M Dils ${ }^{3}$, Richard W McDowell ${ }^{4}$, Val Smith ${ }^{5}$,
} Yvonne R McElarney, Mike Dunbar ${ }^{3}$, and Donal Daly ${ }^{6}$

Despite widespread implementation of best management practices, sustainable farming is neither practical nor possible in certain locations, where protecting water quality and promoting agricultural production are likely to be incompatible. Some strategic prioritization of land-use options and acceptance of continually degraded waterbodies may be required to ensure optimization of multiple ecosystem services in catchments (also known as watersheds or drainage basins). We examine approaches to prioritization and propose catchment buffering capacity as a concept to manage the pressure-impact relationship between land use and aquatic ecosystems. Catchment buffering capacity can be considered as a continuum of biogeochemical, hydrological, and ecological catchment properties that define this relationship. Here, we outline a conceptual framework to assist prioritization: (1) establish a water-quality target, (2) quantify the gap in compliance to achieve the desired target, (3) assess catchment sensitivity to change, and (4) determine the adaptive capacity of catchment communities to reach the target.

Front Ecol Environ 2016; 14(6): 325-332, doi: 10.1002/fee.1296

A cross the globe, over the past century, the intensification of agriculture has resulted in the degradation of natural ecosystems. There has been no greater demonstration of this impact than on aquatic ecosystems - with extensive land clearance, artificial drainage, nutrient inputs, pesticide use, and tillage practices all contributing to a deterioration in water quality and biodiversity (Moss 2008; Smith and Schindler 2009; Dodds et al. 2013). In the past 40 years, a plethora of voluntary, incentivized, and regulatory controls have been introduced to help curb and reverse the impact of modern agriculture on water quality (OECD 2012). Realizing this desired outcome has been complicated by uncertainties over ecological recovery trajectories, the continued impact of historical land-use practices, the difficulties of generating

\section{In a nutshell:}

- Productive agriculture and protection of water quality are incompatible in many catchments

- Prioritization of catchment land use is therefore required to optimize the delivery of multiple ecosystem services

- Catchment buffering capacity provides a basis for managing the pressure-impact relationship between land use and aquatic ecosystems

- Catchment buffering is incorporated into a prioritization framework to inform decision making on catchment management

\footnotetext{
${ }^{1}$ Agri-Food and Biosciences Institute, Belfast, UK ${ }^{*}$ (donnacha.doody@ afbini.gov.uk); ${ }^{2}$ Bangor University, Bangor, UK; ${ }^{3}$ Environment Agency, Wallingford, UK; ${ }^{4}$ AgResearch, Invermay Agricultural Centre, Mosgiel, New Zealand; ${ }^{5}$ University of Kansas, Lawrence, KS; ${ }^{6}$ Environmental Protection Agency, Dublin, Ireland; ${ }^{\dagger}$ these authors contributed equally to this work
}

evidence unequivocally linking cause and effect, and the reluctance to jeopardize productivity with overly restrictive regulation of agricultural practices (Allan 2004; McGonigle et al. 2012; Page et al. 2012).

As the complexity of the effects of agricultural land use on water quality and aquatic ecology is better recognized (Burcher et al. 2007), the global human population continues to rise unabated. The Food and Agriculture Organization of the United Nations (FAO) estimated that if current patterns of food consumption persist, $60 \%$ more food will need to be produced worldwide by 2050 , as compared with that produced from 2005-2007 (FAO 2009). In response, future growth targets for agriculture in many countries will inevitably place further regional pressure on waterbodies unless agricultural intensification can be achieved sustainably (Pretty 2008; Garnett et al. 2013). However, our ability to predict where the dual objectives of agricultural intensification and preservation of water quality are achievable is still limited (Moss 2008), although operational frameworks for linking landscape features and functionality with water-quality protection have been proposed (eg Gascuel-Odoux et al. 2009).

The desire to protect water quality and deliver agricultural growth may be unattainable in many catchments (also termed watersheds or drainage basins). In areas with challenging climate, topography, soil types, and/or extensive subsurface drainage, it may not be possible to achieve sustainable intensification (Doody et al. 2012). In some areas in England, substantial areas of land would need to come out of intensive agricultural production to meet nitrate standards in drinking water, as defined by the European Nitrates Directive. In freshwater habitats, phosphorus standards set under the EU Water Framework Directive (WFD) can be 


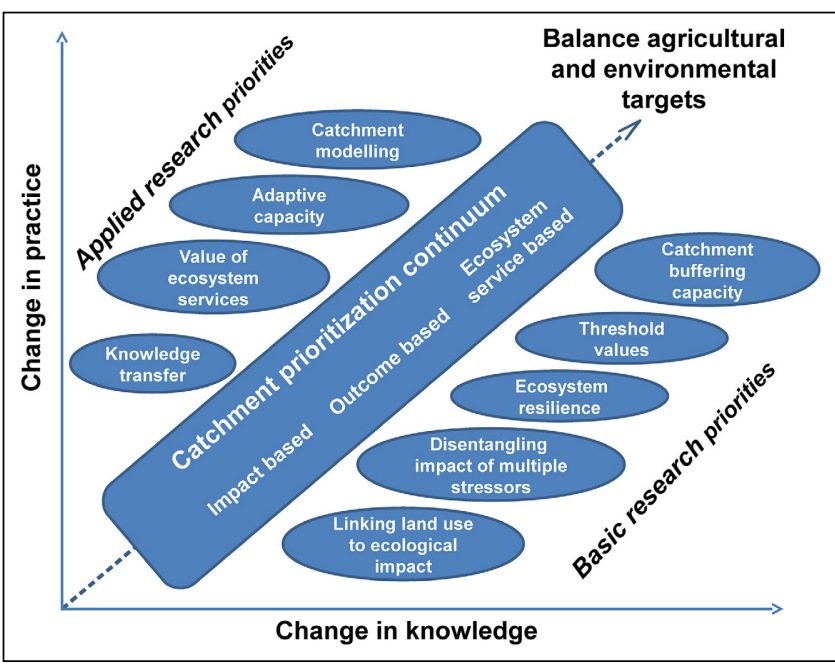

Figure 1. Transformation framework representing the change in practices and knowledge required to progress from impact-based catchment prioritization to ecosystem services-based prioritization. The framework proposes, in the context of balancing agriculture and water-quality targets, the applied and basic research priorities that need to be addressed if this transformation is to occur. The figure is adapted from SLIM (2004), which provides more details on transformation frameworks.

exceeded even when best management practices (BMPs) are implemented (Withers et al. 2014). Some strategic prioritization of land use and acceptance of degraded waterbodies may therefore be necessary to ensure the sustainability and optimization of a range of anthropogenic activities, including agriculture (Doody et al. 2014). Currently in the European Union (EU), this principle is not acceptable since one of the main objectives of the WFD is to prevent deterioration in the status of aquatic ecosystems. Prioritization requires an understanding of waterbody sensitivity to anthropogenic pressure (ie the pressure-impact relationship) from sustainable intensification.

The difficulty in balancing ecosystem services in all catchments suggests that a pragmatic approach is needed to prioritize catchments based on their ability to deliver aquatic and/or agricultural ecosystem services (Doody et al. 2014; Jarvie and Jenkins 2014). We examine approaches to prioritization and consider how the concept of catchment buffering capacity could be utilized to achieve this in the context of nutrient use in agriculture. We use the example of phosphorus (P) to develop a framework to facilitate the determination of where sustainable intensification is most likely to be achieved.

\section{Catchment prioritization}

For many years, catchments have been prioritized to improve water quality, so as to ensure the best use of limited resources (human and financial) and to optimize the cost effectiveness of interventions (eg Barataud et al. 2014). To date, most of these efforts have focused on impact-based prioritization, where resources are targeted to agricultural areas predicted by modeling assessments to have the greatest impact on water quality (eg Heathwaite et al. 2005). For instance, catchments in England have been prioritized for nonpoint source mitigation under the EU WFD, where evidence indicates that nutrient pollution from farming contributes to failure in achieving "good" or "high ecological status" (Environment Agency 2014a). However, despite the widespread implementation of impact-based prioritization of catchments, demonstrating success has been challenging (Doody et al. 2012; Page et al. 2012), as evidenced by the case of Ireland's Lough Melvin catchment. The catchment is characterized by low-intensity farming; nevertheless, a substantial decline in water quality was not averted by mitigation efforts due to limited knowledge regarding farming practices, catchment hydrology, and lake sensitivity (Doody et al. 2012).

More recently, there has been a shift (Figure 1) toward outcome-based prioritization, where catchments are selected for intervention based on the probability of achieving positive chemical or ecological outcomes. In New Zealand, legislation has created a framework to prioritize catchment actions partly based on communityaccepted outcomes for water quality. The National Policy Statement on Freshwater Management (MFE 2014) sets national values for "ecosystem health" and "human health for recreation", but the inclusion of other "optional" values - such as fishing, irrigation, and food production allows local catchment stakeholders to prioritize catchment outcomes based on community values and therefore the provision of valued ecosystem services.

Full progression toward catchment prioritization based on multiple ecosystem services (Figure 1) is currently constrained by the difficulty of linking land-use activities to their effects on waterbodies (Moss 2008), resolving conflicts between achieving different types of services, and uncertainties over the beneficiaries and governance of these services (Bennett et al. 2015). Despite equally important legal, ethical, and social issues surrounding the prioritization of catchments, accurate assessment of the economic trade-offs required to deliver ecosystem services will be a key driver in determining the balance between future agricultural and environmental targets in catchments (Dodds et al. 2013). Withers et al. (2014) noted unsustainable runoff $\mathrm{P}$ concentrations at two UK sites that contained agronomic optimum soil $\mathrm{P}$ levels and that were farmed according to soil fertility BMPs. In such cases, a lower critical threshold for soil P - which would potentially compromise agronomic production - may be required to protect water quality. Progress in resolving these tradeoffs and managing the pressure-impact relationships that exist between catchment ecosystem services is vital in order to identify locations in catchments where sustainable intensification can be achieved. This requires a flexible conceptual framework that can account for catchment sensitivity to multiple anthropogenic pressures. 


\section{Catchment buffering capacity}

One well-established concept that applies to all natural systems is buffering capacity - the ability of a system to resist change in response to an external stimulus. Buffering capacity has been used in the context of soils, waterbodies, and catchments to evaluate soil nutrient availability, hydrologic residence times, regime shifts in aquatic ecosystems, and acidification (Leibowitz et al. 2000; Schippers et al. 2006; Fraterrigo and Downing 2008; Nair 2014). In each case, a system that is well buffered will be less sensitive to disturbance and will be better able to absorb the impact of a stressor for longer as compared with a poorly buffered system. The buffering capacity of a system will eventually reach a threshold (saturation) level, defined here as the point at which small changes in the inputs to a catchment cause a rapid change in the aquatic ecosystem (Figure 2). In his seminal review, Allan (2004) found studies suggesting that river ecology would not be adversely affected until agriculture occupied a percentage - ranging from $30 \%$ to $80 \%$ - of the catchment area. Also, Barry and Foy (2016) demonstrated a substantial variation in the relationship between river soluble reactive phosphorus (SRP) concentrations and agricultural intensity in headwater catchments in Northern Ireland (Figure 3a). We hypothesize that the variability in catchment P response described by Barry and Foy (2016) and Allan (2004) results from variations in catchment buffering capacity arising from differences in the physical, chemical, and biological properties that influence the equilibrium between a catchment system and its surrounding environment. Two catchments with the same agricultural intensity may therefore have different outcomes in terms of impacts on aquatic ecosystems (Figures 3 and 5). In this way, catchment sensitivity to sustainable intensification pressure may be mediated through catchment buffering capacity.

Here we examine the concept of catchment buffering capacity as an approach to managing the pressure-impact relationship between agricultural $\mathrm{P}$, aquatic ecosystems, and multiple ecosystem services. Catchment buffering capacity can be conceptualized as a continuum of biogeochemical, hydrological, and ecological catchment properties that control the pressure-impact relationship between land use and aquatic ecosystems (Figure 3a and b). McDowell et al. (2003) observed that soils and sediments will buffer changes in soil $\mathrm{P}$ concentrations and release to runoff depending on mineral composition, organic matter content, and redox condition (Figure 4). Landscapes buffer the delivery of $\mathrm{P}$ to receiving waters according to the residence time of hydrological pathways, which varies from minutes to years depending on properties such as geology and soil structure (eg Fraterrigo and Downing 2008). Uptake as aboveground biomass (eg in wetlands and riparian areas) plays an important role in landscape buffering (Hattermann et al. 2006). In addition,

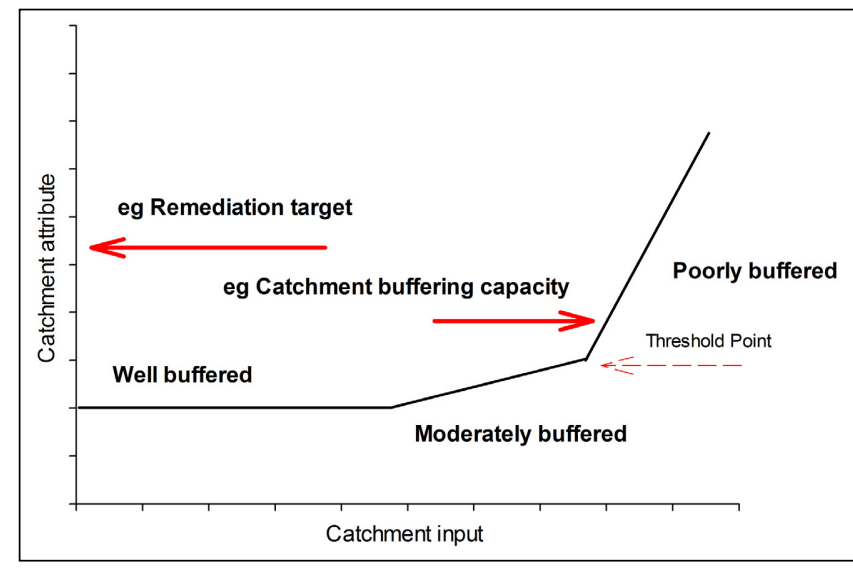

Figure 2. Conceptual framework for the capacity of a catchment to buffer changes in a catchment attribute (eg soluble phosphorus $[P]$ concentrations in the river) in response to nutrient inputs to the catchments (eg $P$ fertilizer inputs). The rate of change in buffer capacity and threshold points are a function of catchment characteristics. The relationship between the remediation target established for the catchment (example indicated on the y axis) and the position of the catchment on the buffering capacity continuum (example indicated on the buffering capacity line) will determine the likelihood of achieving/exceeding the target and therefore the capacity to sustainably intensify agriculture in the catchment.

changes in biodiversity are buffered through complex food web interactions and recolonization routes that influence community-level resistance to impacts from external stressors (Figure 5; Groffman et al. 2006; Dodds et al. 2010). All three buffer components are intrinsically linked in both space and time, and are characterized by their geochemical (eg soil P, lake sediments), hydrological (eg soil water, groundwater), and biomass-related (eg crops, macrophytes, soil microbes) storage capacity (Table 1). We hypothesize that a catchment has a unique buffering capacity signal and that the identification of a threshold point, above which a catchment is poorly buffered, is vital in determining how far agriculture can be intensified in a specific catchment without unduly affecting aquatic ecosystems (Figure 2). For example, in New Zealand catchments, deer farming has a higher $\mathrm{P}$ export than dairy farming due to the former's association with catchments with a lower buffering capacity (Figure 3b; Coop 1965; McDowell and Wilcock 2008).

Despite being a function of the natural landscape (eg soils, geology, hydrology, and stream order), a catchment's innate buffering capacity will be altered over time by anthropogenic activities/impacts such as riparian management, drainage, legacy nutrient effects, and dredging (Table 1). Where catchment buffering capacity is low, sustainable intensification will be more challenging unless technology, innovation, or scientific solutions can facilitate stakeholder's adaption and increase catchment buffering capacity. We therefore envisage that assessing three aspects - namely, potential landscape buffering 

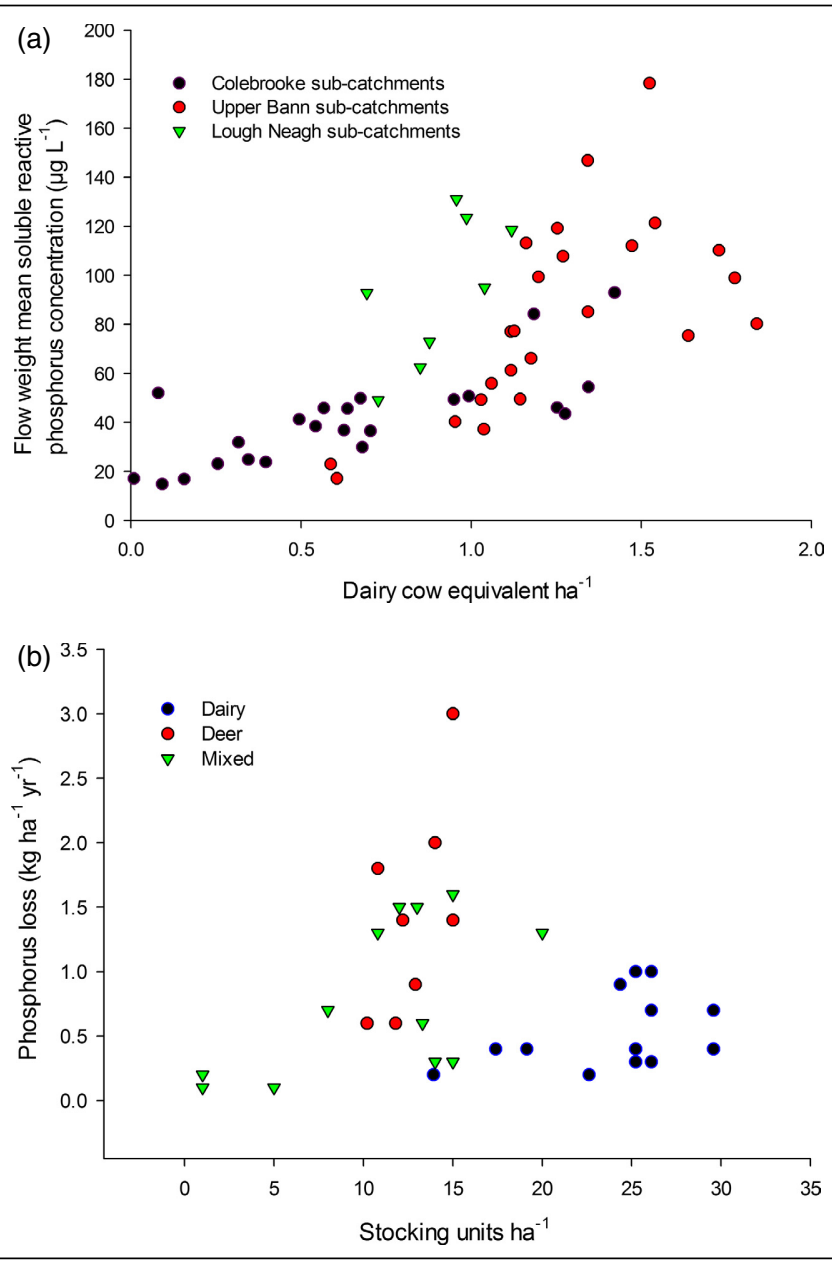

Figure 3. Variation in catchment sensitivity to agricultural pressures as demonstrated by (a) impact of stocking rate (expressed in dairy cow equivalence per hectare; ie where all grazing livestock are theoretically converted to dairy cows) on flow-weighted mean soluble reactive phosphorus (SRP) concentration in the rivers draining the sub-catchments of the Colebrooke and Upper Bann rivers and Lough Neagh in Northern Ireland (McElarney et al. 2015; Barry and Foy 2016) and by (b) annual P loss from a New Zealand catchment dominated by dairy, deer, or mixed (sheep and beef) farming systems (Coop 1965; McDowell and Wilcock 2008). The variation in the relationships expressed in both graphs demonstrates how catchments vary in their abilities to buffer inputs/pressures from agriculture as a function of catchment characteristics.

capacity, how this buffering capacity might be improved (through innovative technologies and engineering), and social engagement to enact necessary change - will be key elements of sustainable watershed management in the future.

\section{A framework for prioritization}

We have proposed buffering capacity as a central concept for the prioritization of catchment ecosystem services, such as between agricultural production and water quality. However, this concept needs to be embedded in a framework through which prioritization can be implemented in practice. In this context, we identify four steps:

(1) Establish a catchment water-quality target. The identification of this target is based on social, economic, and political constructs that define societal goals for a waterbody including - among other things - total maximum daily load, ecological reference conditions, or baseline contaminate concentrations. The European approach has been to set targets based on reference conditions, which are defined for the purposes of the WFD as "the conditions that prevail in the absence or near absence of human disturbance" (Bouleau and Pont 2015);

(2) Quantify the gap between the current and target water quality or ecological condition, and the reductions required from agriculture to close this gap. This will vary on a catchment-specific basis; however, initial results suggest that, on average, agricultural phosphate loads need to be reduced by up to $43 \%$ across England to meet WFD standards (Figure 6) (Environment Agency 2014b);

(3) Identify how well buffered the catchment is and whether the threshold point has been exceeded. If the catchment is poorly buffered, it will be more difficult to achieve a target (Figure 2). Understanding the biogeochemical, hydrological, or ecological cause of poor buffering capacity is important so as to inform the targeting of intervention strategies. Doody

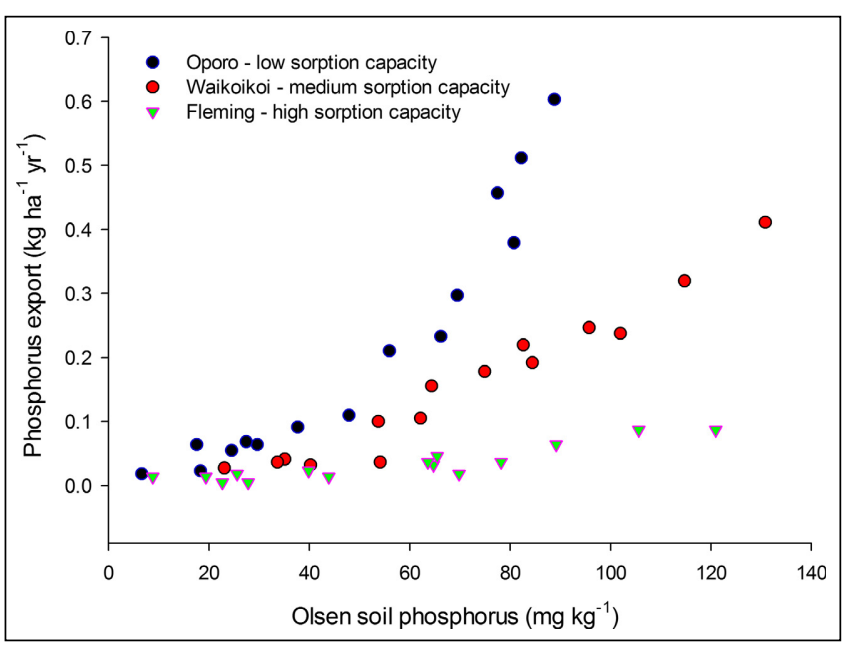

Figure 4. Impact of Olsen P concentration (ie bicarbonateextractable inorganic soil P) on SRP concentration in runoff from three New Zealand soils. The sites differ in their buffering gradients and the threshold point at which SRP concentration in runoff increases sharply. This is due to variation in soil sorption capacity from low (Oporo), to medium (Waikoikoi), to high (Fleming). Adapted from McDowell et al. (2003). 
et al. (2012) demonstrated that rapid runoff in impermeable catchments can lead to large P exports, despite low soil P concentrations;

(4) Assess the ability of catchment communities to make the necessary adaptations to achieve the water-quality target. Adaptive capacity is defined as the precondition that enables adaption to change, including the financial, human, social, natural, and physical capitals that facilitate change (Brown et al. 2010; Lockwood et al. 2015). The adaptive capacity of communities will be affected by their ability to be innovative in implementing mitigation strategies and developing technology.

\section{Discussion}

We have proposed catchment buffering capacity as a central concept for managing catchment sensitivity to sustainable intensification and for prioritizing land-use management for the provision of multiple ecosystem services. New methodologies are now needed to determine catchment buffering capacity and threshold points, and to link these to remediation targets and adaptive capacity. To date, setting targets for improving water quality and for addressing regime shifts in aquatic ecosystems have received more attention (eg Scheffer et al. 2001; Dodds et al. 2010). Identifying changes in catchment buffering capacity and proximity to a threshold may be more easily achieved through the use of longterm historical datasets that span the transition from pristine to impacted states, although the availability of such datasets is very limited (Swetnam et al. 1999). Alternatively, by relying on a range of data-rich catchments with shared characteristics, practitioners could determine comprehensive pressure-impact relationships

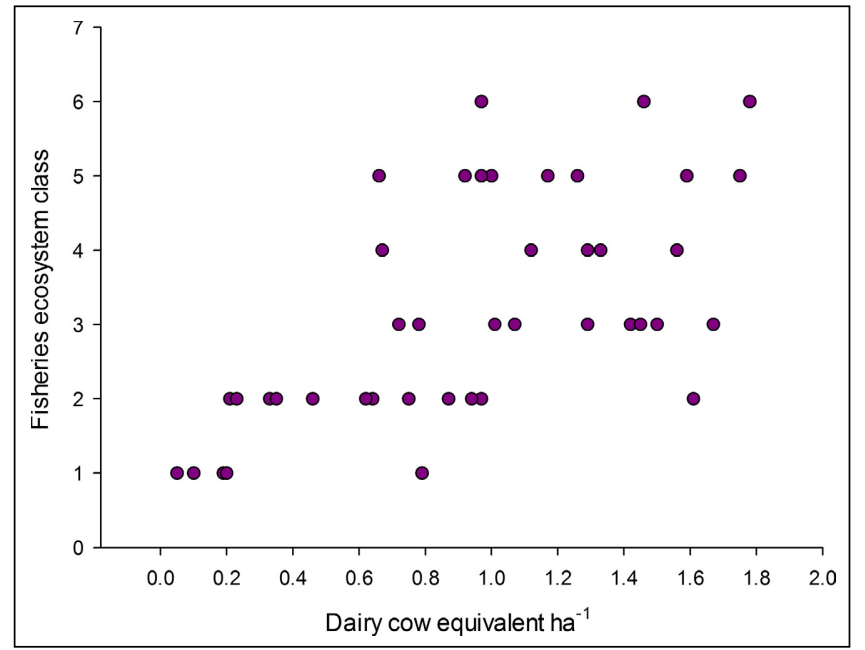

Figure 5. Variation in the sensitivity of aquatic organisms to agricultural intensity (expressed in dairy cow equivalence per hectare) in 42 sub-catchments of the Colebrook and Upper Bann rivers in Northern Ireland (Foy and Kirk 1995).

for particular stressors or ecoregions, similar to identifying reference conditions used for setting targets to control eutrophication (McDowell et al. 2013).

In the context of $\mathrm{P}$, current understanding suggests that natural buffering capacity will be elevated in catchments with highly productive, deep, P-retentive soils; a high base-flow index (ie substantial contribution of groundwater to river flows) and low specific runoff (ie low runoff discharge per unit area of the catchment); and a diverse in-stream ecological community. However, anthropogenic impacts such as enriched soil $\mathrm{P}$ concentrations (legacy soil P), artificial field drainage, and in-channel dredging will substantially reduce catchment $\mathrm{P}$ buffering

Table 1. Indicator and anthropogenic impacts of phosphorus $(P)$ buffering capacity of catchments

\begin{tabular}{lll}
\hline Catchment component & $\begin{array}{l}\text { Indicator(s) of phosphorus } \\
\text { buffering capacity }\end{array}$ & $\begin{array}{l}\text { Factors affecting phosphorus } \\
\text { buffering capacity }\end{array}$ \\
\hline Geochemical storage capacity & - Adsorption capacity (eg Qmax*) & - Legacy soil P \\
& - Parent material & - Manure and fertilizer applications \\
& - Soil pH & - Liming \\
& - Soil organic matter & - Tillage \\
Hydrological storage capacity & - Residence time & - Legacy sediment P \\
& - Q5/Q95 discharge & - Artificial field drainage \\
& - Effective rainfall & - Soil compaction \\
& - Drainage class (eg HOST) & - Wetland destruction \\
& - Hydrological connectivity & - Removal of riparian zones \\
- Bedrock storage & - Loss of floodplains \\
Biomass storage and ecosystem resistance & - Groundwater abstractions \\
(or resilience) & - Sistance to main river channel & - Impoundment \\
& - Stross primary production & \\
& - Trophic status & - Agricultural productivity \\
\hline Notes: *Qmax $=$ maximum Psorption capacity. & - Ecological connectivity & - River alterations \\
\hline
\end{tabular}




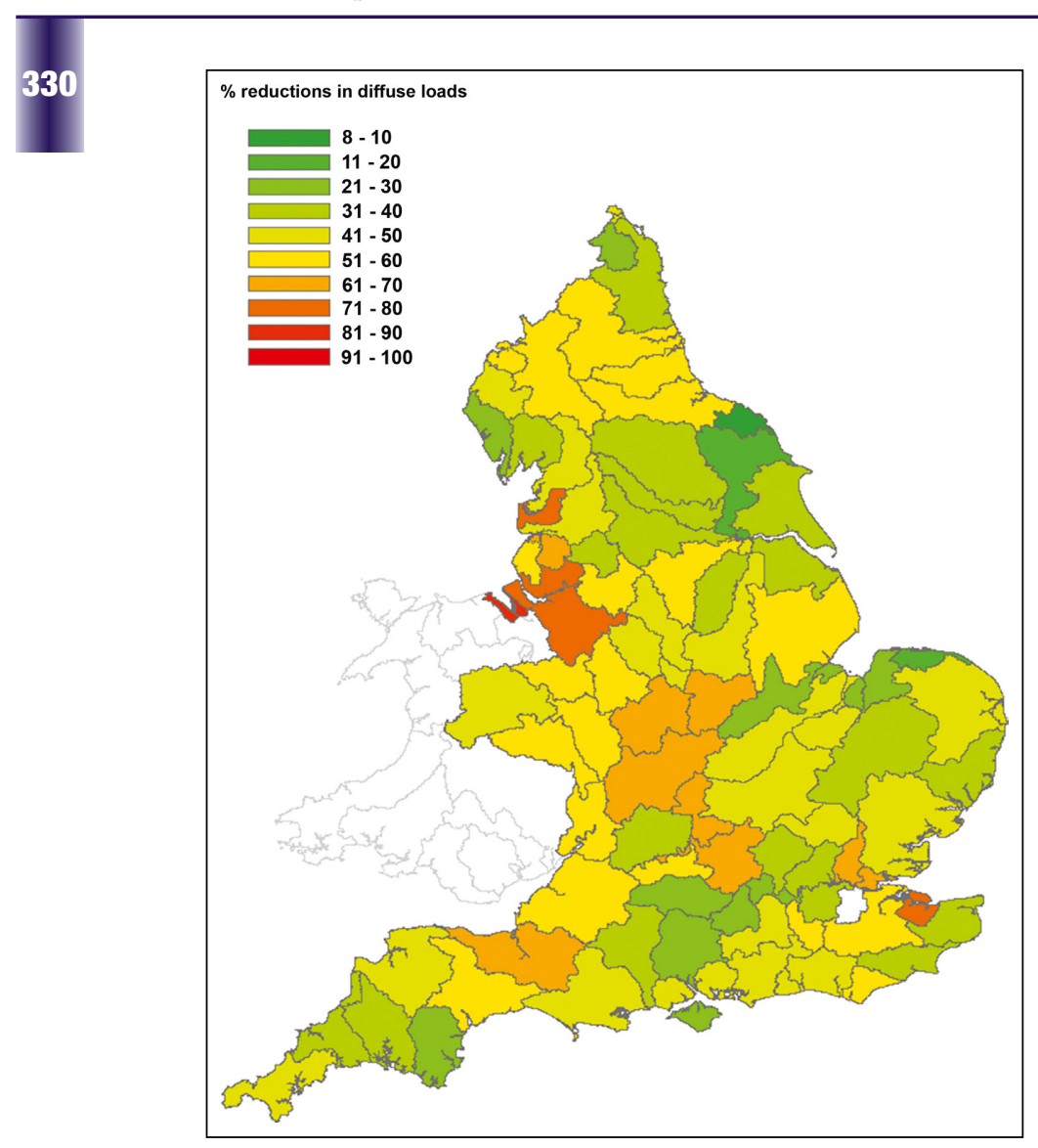

Figure 6. Percent reductions in agricultural $P$ loads required for Water Framework Directive (WFD) compliance, depicted in England (UK) and assessed at the WFD management catchment scale (Environment Agency 2014b).

capacity (Table 1; Blann et al. 2009; Sharpley et al. 2013). The anthropogenic factors that lower catchment buffering capacity will also affect farmers' adaptive capacity. Rowe et al. (2015) highlighted that utilizing legacy soil $\mathrm{P}$ may require lower agricultural $\mathrm{P}$ inputs to reduce the risk posed to water quality. On the other hand, this could compromise agricultural output, especially on housed (ie livestock kept indoors) or partially housed livestock farms, where it is currently uneconomical to transport manure away from farms to distant cropproducing areas. Such a scenario may limit livestock farmers' adaptive capacity, while in other catchments, agricultural impacts may be due to contemporary management practices (eg poor fertilizer and manure management) that farmers can address more readily. In the future, engineering technologies may facilitate the development of new management practices to improve catchment buffering capacity - for example, by redesigning artificial drainage systems and ditch management so as to increase the retention of contaminates during transport (eg Kröger et al. 2013). In this way, a focus on catchment buffering capacity could encourage the creation of additional mitigation measures for eutrophication control and functional land management.
Agricultural codes of basic good practice (CoPs) to control farm-based nutrient pollution have been integrated in cross-compliance rules (ie necessitating that farmers adhere to a set of statutory requirements and BMPs in order to qualify for full subsidy payments) under the Common Agricultural Policy in the EU, the Farm Bill in the US, and in the National Policy Statement on Freshwater Management policy in New Zealand (McDowell et al. 2016). However, there is a need to further develop agricultural $\mathrm{CoPs}$ that account for catchment heterogeneity to maximize ecosystem service provision and enable the implementation of catchmentspecific BMPs to control diffuse pollution from agriculture. Schulte et al. (2014) proposed that an assessment of the functionality of soil resources in catchments would help inform the prioritization of multiple ecosystem services. Adaptive capacity will be a key determinant of the cost-effectiveness of catchment BMPs. In regions with a strong rural economy (eg based on forestry, tourism, or construction), farmers will have more options for off-farm work and/or may also receive incentive payments that help to alleviate any decline in farm profitability resulting from the impact of increased environmental compliance. In addition, farmers require proper educational and extension services to respond to the challenges of sustainable intensification (Buckwell and Armstrong-Brown 2004), with adaption to precision nutrient management unlikely if farmers do not have adequate access to extension services with trained personnel (Davidson et al. 2015).

The prioritization framework outlined here provides a range of outputs - including scenarios 1,2 , and 3 presented in Table 2 - informing the limits of agricultural intensification in individual catchments. The decision to prioritize agriculture and aquatic ecosystems in scenarios 1 and 3, respectively, may be relatively straightforward. For scenario 2, decision makers would have to determine whether (1) the investment required to train farmers and extension services is worthwhile in order to allow agriculture to intensify sustainably and (2) additional assessment is necessary, including establishing nutrient level targets (percent reductions in current nutrient levels) for agricultural operations within a given catchment. Such targets would relate to the current buffering capacity of the catchment, with mitigation strategies optimized within the catchment based on cost-effectiveness. Additional modeling could then be used to estimate the response (eg time lag) of a catchment and the uncertainty in the estimate produced (Howden et al. 2011). The ability of and time required for a catchment to meet a target would be estimated and balanced against the uncertainty associated with achieving the target and the investment necessary to maintain existing infrastructure and economically sustainable agriculture. If the target is not achievable (or after consultation with catchment stakeholders, the uncertainty is considered too great), then this is a signal for revision of the water-quality target, identified in step 1 of 
Table 2. Example scenarios arising from the catchment prioritization process*

\begin{tabular}{llll}
\hline Criterion & Scenario I & Scenario 2 & Scenario 3 \\
\hline Compliance gap & Large & Moderate & Small \\
Buffering capacity & Low & Medium & High \\
Proximity to threshold & Exceeded & At & Approaching \\
Adaptive capacity & Low & Limited & High \\
Prioritization outcome & Prioritize agriculture & Conduct further analysis & Prioritize aquatic \\
& & & ecosystems \\
\hline
\end{tabular}

Notes: *Based on identification of the compliance gap to remediation target, catchment buffering capacity, proximity of the catchment to the buffering capacity threshold, and the capacity of the community to adapt to the changes required to achieve the target.

the prioritization framework or, alternatively, for wholesale land-use changes within the catchment.

Although the implementation of a prioritization approach may diverge from contemporary national policy and regulation in many countries, the current waterquality policies in Europe, New Zealand, and the US already provide mechanisms through which a limited prioritization approach could be implemented (McDowell et al. 2016). In each case, alternative targets can be set based on natural landscape conditions and technical infeasibility due to factors such as infrastructure (eg Bouleau and Pont 2015). With regard to the EU WFD and US Clean Water Act, the social and economic impacts of achieving a designated target can also be considered through Article 4.5 and Use Attainability Analysis, respectively. In both cases, alternative waterquality objectives can be set if the cost of achieving a desired target is deemed unduly expensive or if a human activity supported by a waterbody is considered essential to society.

\section{Conclusions}

Our arguments for prioritization are not intended to advocate for the acceptance of unabated nutrient pollution in catchments prioritized for agriculture. Instead we argue that less stringent application and enforcement of environmental regulations, focused on targets of "continual improvement" or "stabilization" in water quality, should be applied in catchments where agricultural production is prioritized, or where production is not adversely affecting ecological status. Stricter regulations will be required, on a targeted risk-based approach, where the probability of aquatic ecosystem recovery is highest. A minimum standard of agricultural BMPs should be applied in all catchments to provide a basic level of environmental protection. Thereafter, an adaptive system of policy intervention could be implemented, including guidance, voluntary approaches, economic incentives, and new regulations. The conceptual framework outlined here places catchment buffering capacity at the center of the prioritization approach. Further research is required to develop this concept for various catchment typologies across ecoregions and for multiple stressors. Phosphorus is just one of multiple stressors affecting aquatic ecosystems - with each catchment having a unique group of stressors that are a function of its multifaceted, heterogeneous nature, and anthropogenic activities that dominate its land use to varying degrees. Disentangling the effects of these multiple stressors at the catchment scale remains difficult, but is a vital step toward prioritizing catchments. Though examined here in the context of agricultural $\mathrm{P}$, the buffering capacity concept should be evaluated to assess its applicability to non-chemical stressors such as sediments and hydromorphology.

\section{Acknowledgements}

Any views expressed here are those of the authors, and do not necessarily reflect those of the organizations with which they are affiliated. We acknowledge the support of the Phosphorus Research Coordination Network run by Arizona State University, where discussions on this paper occurred. This paper is dedicated to the memory of our colleague Val Smith, who sadly passed away just as this paper was being published.

\section{References}

Allan JD. 2004. Landscapes and riverscapes: the influence of land use on stream ecosystems. Annu Rev Ecol Evol S 35: 257-84.

Barataud F, Durpoix A, and Mignolet C. 2014. Broad analysis of French priority catchment areas: a step toward adaption of the Water Framework Directive? Land Use Policy 36: 427-40.

Barry C and Foy R. 2016. Assessing the success of regional measures for lowering agricultural nutrient pollution in headwater streams. J Environ Qual; doi:10.2134/jeq2015.04.0184.

Bennett EM, Cramer W, Begossi A, et al. 2015. Linking biodiversity, ecosystem services, and human well-being: three challenges for designing research for sustainability. Curr Opin Environ Sustain 14: 76-85.

Blann KL, Anderson JL, Sands GR, and Vondracek B. 2009. Effects of agricultural drainage on aquatic ecosystems: a review. Crit Rev Env Sci Tec 39: 909-1001.

Bouleau G and Pont D. 2015. Did you say reference conditions? Ecological and socio-economic perspectives on the European Water Framework Directive. Environ Sci Policy 47: 32-41.

Brown PR, Nelson R, Jacobs B, et al. 2010. Enabling natural resource managers to self-assess their adaptive capacity. Agr Syst 103: 562-68. 
Buckwell A and Armstrong-Brown S. 2004. Changes in farming and future prospects - technology and policy 1. Ibis 146: 14-21.

Burcher CL, Valett HM, and Benfield EF. 2007. The land cover cascade: relationships coupling land and water. Ecology 88: 228-42.

Coop IE. 1965. A review of the ewe equivalent system. New Zealand Agr Sci 1: 13-18.

Davidson EA, Suddick EC, Rice CW, and Prokopy LS. 2015. More food, low pollution (Mo Fo Lo Po): a grand challenge for the 21st century. J Environ Qual 44: 305-11.

Dodds WK, Clements WH, Gido K, et al. 2010. Thresholds, breakpoints, and nonlinearity in freshwaters as related to management. J N Am Benthol Soc 29: 988-97.

Dodds WK, Perkin JS, and Gerken JE. 2013. Human impact on freshwater ecosystem services: a global perspective. Environ Sci Technol 47: 9061-68.

Doody DG, Foy RH, and Barry CD. 2012. Accounting for the role of uncertainty in declining water quality in an extensively farmed grassland catchment. Environ Sci Policy 24: 15-23.

Doody DG, Withers PJA, and Dils RM. 2014. Prioritizing waterbodies to balance agricultural production and environmental outcomes. Environ Sci Technol 48: 7697-99.

Environment Agency. 2014a. Catchment Sensitive Farming Evaluation Report - Phases 1 to 3 (2006-2014). http://publications. naturalengland.org.uk/category/6919090. Viewed 18 May 2016.

Environment Agency. 2014b. Progressing towards WFD objectives - the role of agriculture. London, UK: Environment Agency.

FAO (Food and Agriculture Organization of the United Nations). 2009. How to feed the world in 2050. www.fao.org/fileadmin/ templates/wsfs/docs/expert_paper/How_to_Feed_the_World_ in_2050.pdf. Viewed 18 May 2016.

Foy $\overline{\mathrm{RH}}$ and Kirk M. 1995. Agriculture and water quality: a regional study. Water Environ J 9: 247-56.

Fraterrigo JM and Downing JA. 2008. The influence of land use on lake nutrients varies with watershed transport capacity. Ecosystems 11: 1021-34.

Garnett T, Appleby MC, Balmford A, et al. 2013. Sustainable intensification in agriculture: premises and policies. Science 341: 33-34.

Gascuel-Odoux C, Massa F, Durand P, et al. 2009. Framework and tools for agricultural landscape assessment relating to water quality protection. Environ Manage 43: 921-35.

Groffman PM, Baron JS, Blett T, et al. 2006. Ecological thresholds: the key to successful environmental management or an important concept with no practical application? Ecosystems 9: 1-13.

Hattermann FF, Krysanova V, Habeck A, and Bronstert A. 2006. Integrating wetlands and riparian zones in river basin modelling. Ecol Model 199: 379-92.

Heathwaite AL, Quinn PF, and Hewett CJM. 2005. Modelling and managing critical source areas of diffuse pollution from agricultural land using flow connectivity simulation. J Hydrol 304: 446-61.

Howden NJK, Burt TP, Mathias SA, et al. 2011. Modelling longterm diffuse nitrate pollution at the catchment-scale: data, parameter and epistemic uncertainty. J Hydrol 403: 337-51.

Jarvie HP and Jenkins A. 2014. Accounting for ecosystem services in water quality standards compliance. Environ Sci Technol 48: 14072-74.

Kröger R, Dunne EJ, Novak J, et al. 2013. Downstream approaches to phosphorus management in agricultural landscapes: regional applicability and use. Sci Total Environ 442: 263-74.

Leibowitz SG, Loehle C, Li BL, and Preston EM. 2000. Modeling landscape functions and effects: a network approach. Ecol Model 132: 77-94.

Lockwood M, Raymond CM, Oczkowski E, and Morrison M. 2015. Measuring the dimensions of adaptive capacity: a psychometric approach. Ecol Soc 20: 37.

McDowell RW and Wilcock RJ. 2008. Water quality and the effects of different pastoral animals. New Zealand Vet J 56: 289-96.
McDowell RW, Dils RM, Collins AL, et al. 2016. A review of the policies and implementation of practices to decrease water quality impairment by phosphorus in New Zealand, the UK, and the US. Nutr Cycl Agroecosys 104: 289-305.

McDowell RW, Monaghan RM, and Morton J. 2003. Soil phosphorus concentrations to minimise potential $\mathrm{P}$ loss to surface waters in Southland. New Zealand J Agr Res 46: 239-53.

McDowell RW, Snelder TH, Cox N, et al. 2013. Establishment of reference or baseline conditions of chemical indicators in New Zealand streams and rivers relative to present conditions. Mar Freshwater Res 64: 387-400.

McElarney Y, Rippey B, Rosell R, et al. 2015. Development of targeted ecological modelling tools for lake management (DOLMANT) - technical report. EU INTERREG IVA Crossborder Programme. https://www.afbini.gov.uk/articles/dolmant-development-lake-management-tools\#toc-5.

McGonigle DF, Harris RC, McCamphill C, et al. 2012. Towards a more strategic approach to research to support catchmentbased policy approaches to mitigate agricultural water pollution: a UK case-study. Environ Sci Policy 24: 4-14.

MFE (Ministry for Environment - New Zealand). 2014. National Policy Statement for Freshwater Management. Publication reference number ME 1155. www.mfe.govt.nz/node/19456. Viewed 18 May 2016.

Moss B. 2008. Water pollution by agriculture. Philos T Roy Soc B 363: 659-66.

Nair VD. 2014. Soil phosphorus saturation ratio for risk assessment in land use systems. Front Environ Sci 2; doi:10.3389/ fenvs.2014.00006.

OECD (Organisation for Economic Cooperation and Development). 2012. Water quality and agriculture: meeting the policy challenge. Paris, France: OECD Studies on Water, OECD Publishing; doi:10.1787/9789264168060-en.

Page T, Heathwaite AL, Moss B, et al. 2012. Managing the impacts of nutrient enrichment on river systems: dealing with complex uncertainties in risk analysis. Freshwater Biol 57: 108-23.

Pretty J. 2008. Agricultural sustainability: concepts, principles and evidence. Philos T Roy Soc B 363: 447-65.

Rowe H, Withers PJA, Baas P, et al. 2015. Integrating legacy soil phosphorus into sustainable nutrient management strategies for future food, bioenergy and water security. Nutr Cycl Agroecosys; doi:10.1007/s10705-015-9726-1.

Scheffer M, Carpenter S, Foley JA, et al. 2001. Catastrophic shifts in ecosystems. Nature 413: 591-96.

Schippers P, van de Weerd H, De Klein J, et al. 2006. Impacts of agricultural phosphorus use in catchments on shallow lake water quality: about buffers, time delays and equilibria. Sci Total Environ 369: 280-94.

Schulte RP, Creamer RE, Donnellan T, et al. 2014. Functional land management: a framework for managing soil-based ecosystem services for the sustainable intensification of agriculture. Environ Sci Policy 38: 45-58.

Sharpley A, Jarvie HP, Buda A, et al. 2013. Phosphorus legacy: overcoming the effects of past management practices to mitigate future water quality impairment. J Environ Qual 42: 1308-26.

SLIM (Social Learning for the Integrated Managing and sustainable use of water at catchment scale). 2004. Social learning as a policy approach for sustainable use of water. http://bit.ly/1qrM5Uf. Viewed 18 May 2016.

Smith VH and Schindler DW. 2009. Eutrophication science: where do we go from here? Trends Ecol Evol 24: 201-07.

Swetnam TW, Allen CD, and Betancourt JL. 1999. Applied historical ecology: using the past to manage for the future. Ecol Appl 9: 1189-206.

Withers PJA, Neal C, Jarvie HP, and Doody DG. 2014. Agriculture and eutrophication: where do we go from here? Sustainability 6 : 5853-75. 